\title{
The microphytobenthos of Königshafen - spatial and seasonal distribution on a sandy tidal flat
}

\author{
R. M. Asmus ${ }^{1} \&$ E. Bauerfeind ${ }^{2}$ \\ ${ }^{1}$ Biologische Anstalt Helgoland, Wattenmeerstation Sylt; D-25992 List, \\ Federal Republic of Germany \\ ${ }^{2}$ Institut für Meereskunde; SFB 313, Heinrich-Hecht-Platz 10, D-24118 Kiel, \\ Federal Republic of Germany
}

\begin{abstract}
A microphytobenthic species composition of a tidal flat in the northern Wadden Sea was analysed regarding cell numbers and biomass (in carbon units). The three sampling sites differed in tidal inundation from $15 \mathrm{~cm}$ to about $90 \mathrm{~cm}$ water depth at high tide. The sediment was sandy at all three stations. A cluster analysis revealed a separation of the benthic diatoms into three areas: a Nereis-Corophium-belt, a seagrass-bed and the Arenicola-flat. Small epipsammic diatoms were most abundant and dominated the microalgal biomass. A microphytobenthic "spring bloom" even started beneath the ice cover of the flat in January. Lowest values of cell numbers and biomass of benthic microalgae were found in summer. Highest values were measured in the uppermost area (Nereis-Corophium-belt), and only here was an autumnal increase of benthic microalgae found. Further cluster analysis within each of the three areas revealed seasonal differences although the majority of species were present all year round. Many species were most abundant in spring, and some showed a bimodal distribution (spring-autumn) in the year of investigation.
\end{abstract}

\section{INTRODUCTION}

Although benthic diatoms are ecologically very important in the Wadden Sea, the species composition has only once before been quantified with regard to seasonal and spatial differences or similarities (Colijn \& Dijkema, 1981). Much more attention has been paid to the species composition of phytoplankton. However, both groups of primary producers are important in the Wadden Sea - phytoplankton more in deeper waters, whereas microphytobenthos dominates on shallow tidal flats. The primary production of both pelagic and benthic microalgae has been measured intensively (Cadée, 1980).

In the past, important taxonomical work has been done on benthic diatoms in the Wadden Sea. The inventory of diatom species in this area has been clarified by Hustedt $(1939,1959)$ considering also the quantitatively important small species found between the river Elbe and the Ems-Dollard-estuary. Van der Werff (1960) was the first to investigate the diatom species of the Ems-Dollard estuary. Brockmann $(1935,1950)$ studied benthic diatoms mainly taxonomically, but also tried to distinguish sociological entities for the first time in the northern Wadden Sea (Brockmann, 1950). These studies were very helpful for species identification and include valuable hints gained from long experience, showing species which may be "typical" for certain sediment types. The first systematic investigations of the spatial distribution of benthic diatoms in areas of the 
Wadden Sea in summer months were published by Colijn \& Koeman (1975) and Colijn \& Nienhuis (1978).

The species composition and abundance of microphytobenthos are influenced (in addition to light) by physical factors such as sediment characteristics (Amspoker \& McIntire, 1978; Whiting \& McIntire, 1985; Gätje, 1992), temperature (van den Hoek et al., 1979, Snoeijs, 1989), and desiccation (McIntire \& Overton, 1971). Salinity becomes important to diatoms in estuaries (Van der Werff, 1960; McIntire \& Overton, 1971; Amspoker \& McIntire, 1986). Also water currents, waves, turbulence and other weather conditions can have a strong impact on the benthic diatom assemblages (Amspoker, 1977; Colijn \& Dijkema, 1981; Korte \& Blinn, 1983; de Jonge, 1992). Out of the multitude of chemical compounds in sediments, inorganic nutrients promote microphytobenthos (Sundbäck \& Snoeijs, 1991). The toxic substance hydrogen sulphide can be tolerated by many benthic diatom species (Admiraal, 1984). Little is known about interactions between benthic micro- and macroalgae, some indications are given by Huang \& Boney (1984) and McIntire \& Overton (1971).

In studies of coastal ecosystems, it is important to collect information about the ecology of benthic microalgae. These algae form a great part of the nutrition for many benthic micro- and macrofauna species. It is not only important to measure the primary production and biomass in terms of chlorophyll - the microbenthic species composition should also be considered. Diatoms have developed a large variety of size, shape and growth forms. For the functioning of an ecosystem, it is important to know, if, for example, small epipsammic or large epipelic species dominate and which ones are the preferred food source.

The questions asked in this investigation are, whether there are different assemblages of benthic microalgae found at three localities of similar sediment characteristics, situated at different tidal levels, and whether there are seasonal differences. Have similar assemblages of benthic diatoms been found in other comparable coastal environments?

\section{MATERIAL AND METHODS}

\section{Study site}

This study was carried out at 3 sites of the sandy part of the Königshafen bay (Wadden Sea near the island of Sylt, eastern North Sea, $55^{\circ} 03^{\prime} \mathrm{N}, 8^{\circ} 25^{\prime}$ E) (Fig. 1). Water depth at high tide in the sampling field of the Arenicola-flat is about $0.90 \mathrm{~m}$ (corresponding to an inundation time of $6 \mathrm{~h}$ ), $0.50 \mathrm{~m}$ in the seagrass-bed (about $5 \mathrm{~h}$ of inundation) and $0.20 \mathrm{~m}$ in the Nereis-Corophium-belt ( $2 \mathrm{~h}$ of inundation). In each of these communities, a test field of $5 \times 5 \mathrm{~m}$ was staked off. The sediment is mainly ( 40 to $60 \%$ ) composed of sand grains in the fraction of $0.15-0.355 \mathrm{~mm}$ (PHI 2.75-1.5). Fractions smaller than $0.063 \mathrm{~mm}$ and 0.09 to $0.15 \mathrm{~mm}$ (PHI 3.5-2.75) comprise less than $5 \%$. More than $20 \%$ are in the

Fig. 1. a: Position of the island of Sylt in the northern Wadden Sea, b: Königshafen at the northern tip of the island of Sylt (coarsely dotted). The sampling points are indicated by circles in the Arenicolaflat (white), the seagrass-bed formed by Zostera noltii (chequered) and Nereis-Corophium-belt (lined). Additionally mussel beds (black) and a muddy seagrass bed of Zostera marina (stippled) are indicated 

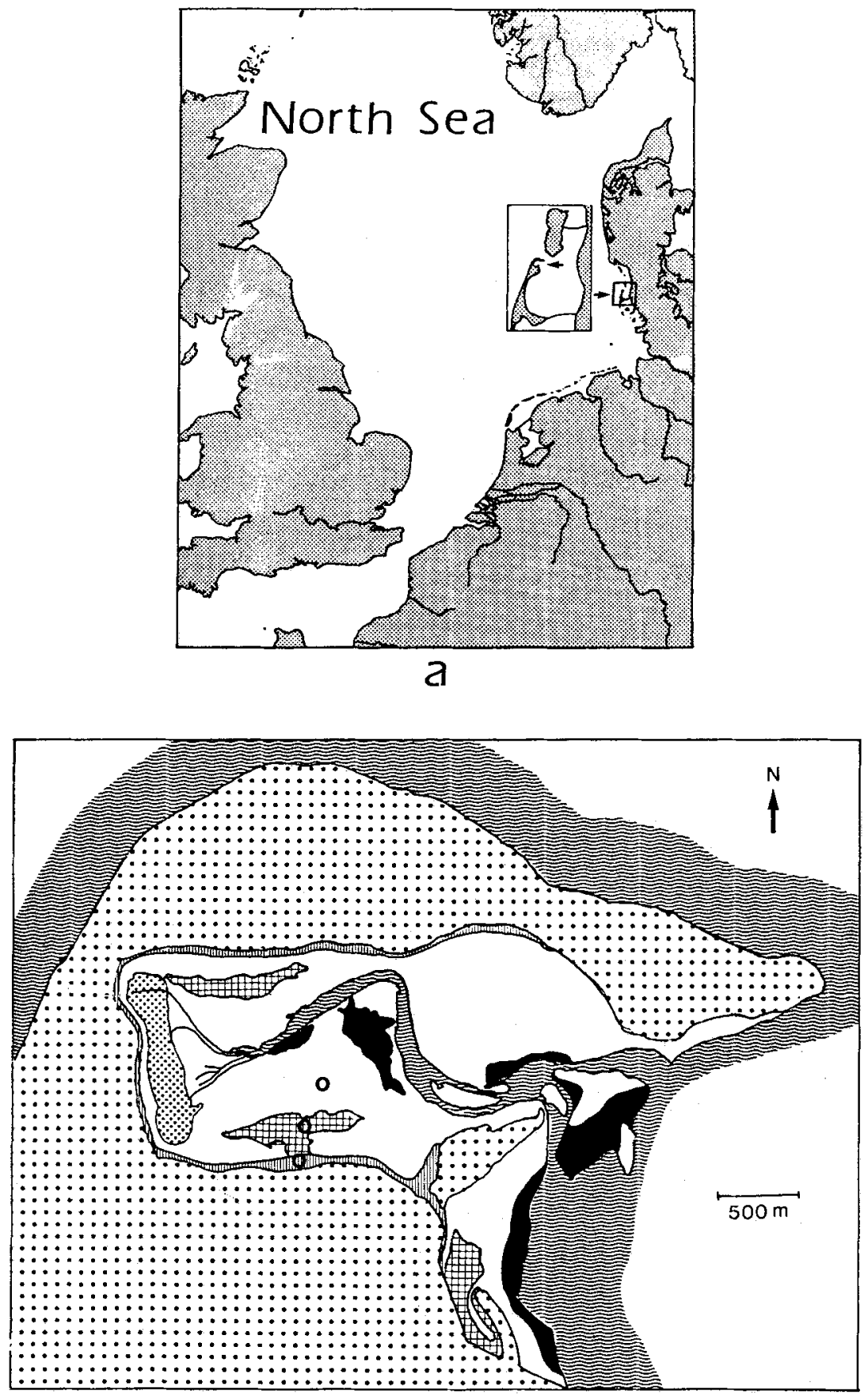

b 
fraction 0.355-0.6 mm (PHI 1.5-0.75) and small shares of 1-5\% are larger than $1.0 \mathrm{~mm}$ (Austen, 1990). Salinity varies seasonally between 26 and 32 psu (practical salinity unit). The tidal flat was covered with ice in the winter of $79 / 80$ in January and February. Sediment samples were taken from beneath the ice in January, and just after thawing in February. Water temperature in summer rarely exceeds $22^{\circ} \mathrm{C}$ (Asmus, 1984).

\section{Sampling, cell counting and biomass calculation}

Four parallel samples $\left(0.64 \mathrm{~cm}^{2} \times 0.3 \mathrm{~cm}\right.$ depth) were taken monthly in 1980 , with a cut off syringe, from each plot. All samples were preserved with formaldehyde until species analysis in 1981. Three parallel samples were cleansed of organic substances by boiling in a mixture of nitric and sulphuric acid (mixed in a relation of 2:1). Subsequently, the diatom samples were rinsed with distilled water ( 10 times). Quantitative subsamples were embedded in "Hyrax". The fourth sample was used for identification and enumeration of species which were subject to destruction by the cleaning technique, such as cyanobacteria and weakly silicified diatoms (e.g. Cylindrotheca gracilis (Brébisson) Grunow). Living cells could only be distinguished from dead ones by intact chloroplasts. The great majority of cells in the sediment surface were alive. Epipsammic diatoms were distinguished from epipelic ones by shaking and decanting of the samples. The distinction in this study made between epipsammic and epipelic species was compared with the lists given by van den Hoek et al. (1979) and Rao \& Lewin (1976).

Valves and cells were counted in a microscope using up to a 400-fold magnification. At least 600 valves were counted per slide. The factors for the calculation of cell numbers per $\mathrm{cm}^{2}$ ranged between 77 and 2647. Most diatom species were identified at higher magnification (1000-fold) in the light microscope, or by scanning electron microscopy (Leitz AMR 1200 B). Diatoms were identified according to Hustedt (1927-30, 1931-59, 1961-66), Cleve-Euler (1951-55), Hendey (1964) and Van der Werff \& Huls (1957-74).

With the aid of the publications by Sundbäck ' $\&$ Medlin (1986) and Sundbäck (1987), the identity of Catenula adhaerens (preliminarily named Amphora cf. staurophora) and Opephora olsenii (misidentified as $O$. pacifica, seagrass-bed) could be clarified.

The biomass of microbenthic algae was calculated via cell volume (Edler, 1979). The shape and size of each species found was measured, plasma volume was calculated, and the biomass in carbon units could be determined.

\section{Cluster analysis}

The analysis of the microphytobenthic community structure was carried out by means of a cluster analysis. The chosen method is based on results derived from the Spearman rank correlation; clusters were constructed by applying the complete linkage procedure (Bock, 1974; Steinhausen \& Langer, 1977). The resulting classification tables and dendrograms were used for illustrating relationships (similarity/dissimilarity) between subgroups of the microphytobenthic community. Dendrograms were constructed by using the "Canberra Matrix"; results are presented as \% dissimilarity $(0-100 \%)$, with the $60 \%$ value marking the border of significant groups. A programme package developed at the SFB 95 at the University of Kiel was used for the cluster analysis. For details see Bölter et al. (1980), Bölter \& Meyer (1986), Meyer (1983) and 
Meyer \& Bölter (1981). The analysis was based on cell numbers in one run and on biomass of the microphytobenthic species in a second run. Considering the importance of the microbenthic algae as a food source for grazing animals (i.e. Hydrobia ulvae), diatom biomass in the sediment may be of more relevance than the cell numbers alone. Thus, special emphasis is given to results based on the analysis of the microphytobenthic biomass.

In this manuscript, the structural analysis is presented, as a part of an investigation of the primary production in Königshafen. Data of the microalgal composition of the Arenicola-flat are already given in Asmus (1982), and the annual course of total microalgal biomass in the three communities has been described in Asmus \& Asmus (1985). Here we present annual courses of cell numbers, size spectra, species composition of benthic microalgae in the seagrass-bed and in the Nereis-Corophium-belt, cluster analyses and dendrograms.

\section{RESULTS}

\section{General characteristics of the microphytobenthic assemblages}

A total of 109 species of microalgae were observed in the sediment samples. Most of the species are benthic diatoms. One species of cyanobacteria, Merismopedia glauca (Ehr.) Naeg., was an important component of the assemblages. Sedimented diatoms of planktonic origin are also included. These species were very rare in the sediment in the year of investigation.

As diatoms are an important food source for deposit feeding animals, the size spectrum of the available diatoms is presented (Fig. 2). In all three areas (Arenicola-flat, seagrass-bed and Nereis-Corophium-belt), small-sized epipsammic diatoms dominated in abundance and in biomass. Additionally, a great number of larger epipsammic and epipelic diatom species were found. Sizes ranged from a few microns in length up to $200 \mu \mathrm{m}$, and in biomass units from 6 to more than $11000 \mathrm{pg} \mathrm{C}$ per cell.

The most abundant species was the small Achnanthes hauckiana Grunow (9-17 $\mu \mathrm{m}$ in apical length), adhering to sand grains. Its contribution to total microphytobenthic biomass (in carbon units) was $52 \pm 19 \%$ (annual mean value with standard deviation) in the Arenicola-flat and $39 \pm 15 \%$ in the seagrass-bed. In the Nereis-Corophium-belt, other small epipsammic species also formed high shares in cell number and biomass. Thus, the share of Achnanthes hauckiana was only $13 \pm 5 \%$. Catenula adhaerens Mereschk., Amphora exigua Greg., Cocconeis sp. 1 and Achnanthes hauckiana together formed $62 \pm 30 \%$ on annual average.

In this study area, the "spring bloom" of microphytobenthos started already in January and lasted till May (Fig. 3). The high microphytobenthic cell numbers as well as biomass values in spring decreased strongly towards summer. An autumnal increase was found only in the Nereis-Corophium-belt. The densest and richest microalgal assemblage developed in the upper part of the tidal flat (Nereis-Corophium-flat).

The standard deviation of the cell counts was small in the Arenicola-flat ( 4 to $15 \%$ ), higher in the seagrass-bed ( 2 to $30 \%$ ) and highest in the Nereis-Corophium-belt ( 8 to $38 \%$ ) (Fig. 3). This is assumed to indicate an increase in patchiness. 


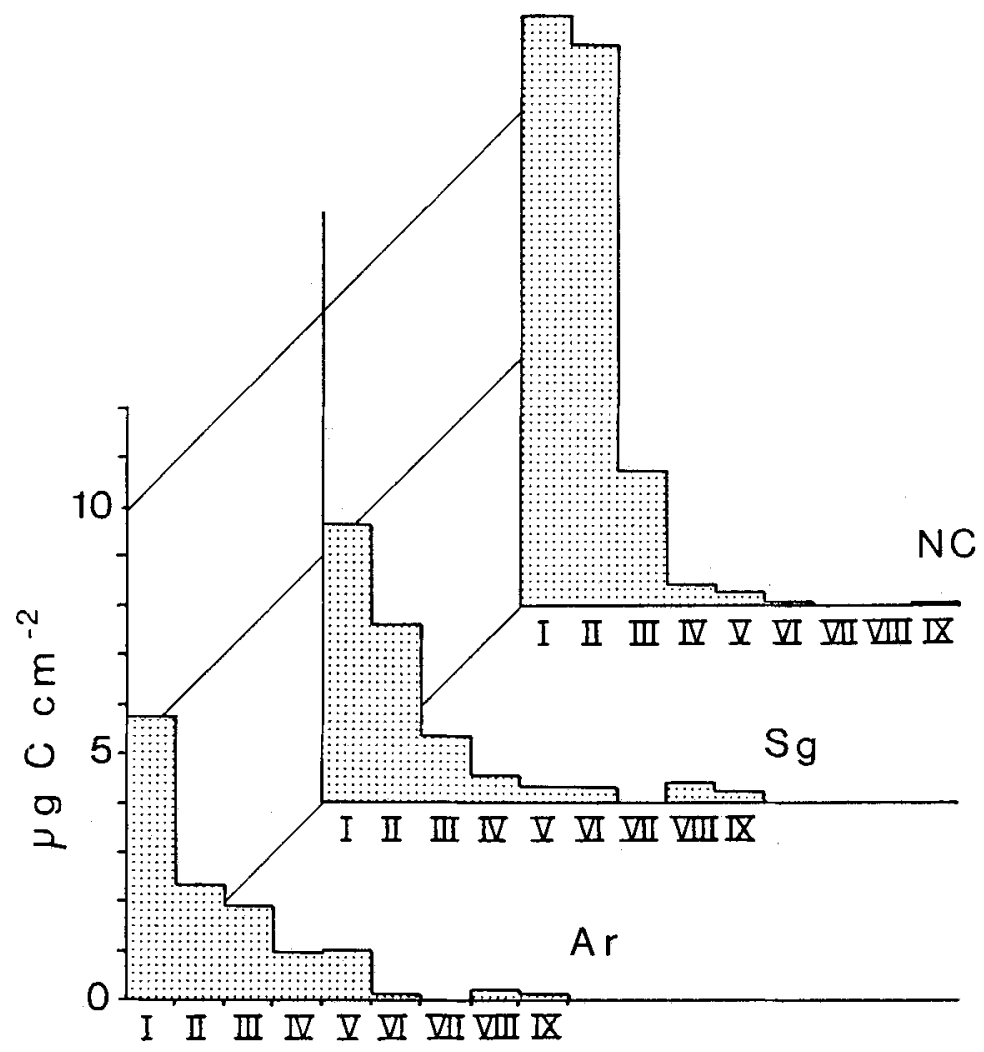

Fig. 2. Size spectrum of benthic diatoms in 3 areas of a sandy tidal flat (Ar: Arenicola-flat, Sg: seagrass-bed, NC: Nereis-Corophium-belt). The size of the diatoms is subdivided into groups according to cell biomass (pg C cell $\left.{ }^{-1}\right)(x$-axis): I 5-50, II 50-200, III 200-500, IV 500-1000, V 1000-2000, VI 2000-3000, VII 3000-4000, VIII 4000-5000, IX > 5000. Annual mean values are given (y-axis)

\section{Spatial distinction of benthic microalgal species}

In the cluster analysis, all lists of the vegetation from the three sites and the whole year were pooled and subsequently sorted by the programme into different groups. Certain conditions could be chosen: all species included $(0-100 \%)$ or dominant species excluded $(0-66 \%)$.

The programme sorted the records firstly into spatial and secondly into seasonal groups. The area from which the samples originated had a greater effect on the separation into groups than the season.

A separation into Arenicola-flat, seagrass-bed and Nereis-Corophium-belt records emerged when the numerically dominant species were excluded (including only 0-66\%) (Table 1). One record (30) stands isolated, and the record 23 , which originated from the Nereis-Corophium-belt, was included by the programme into the seagrass-group 

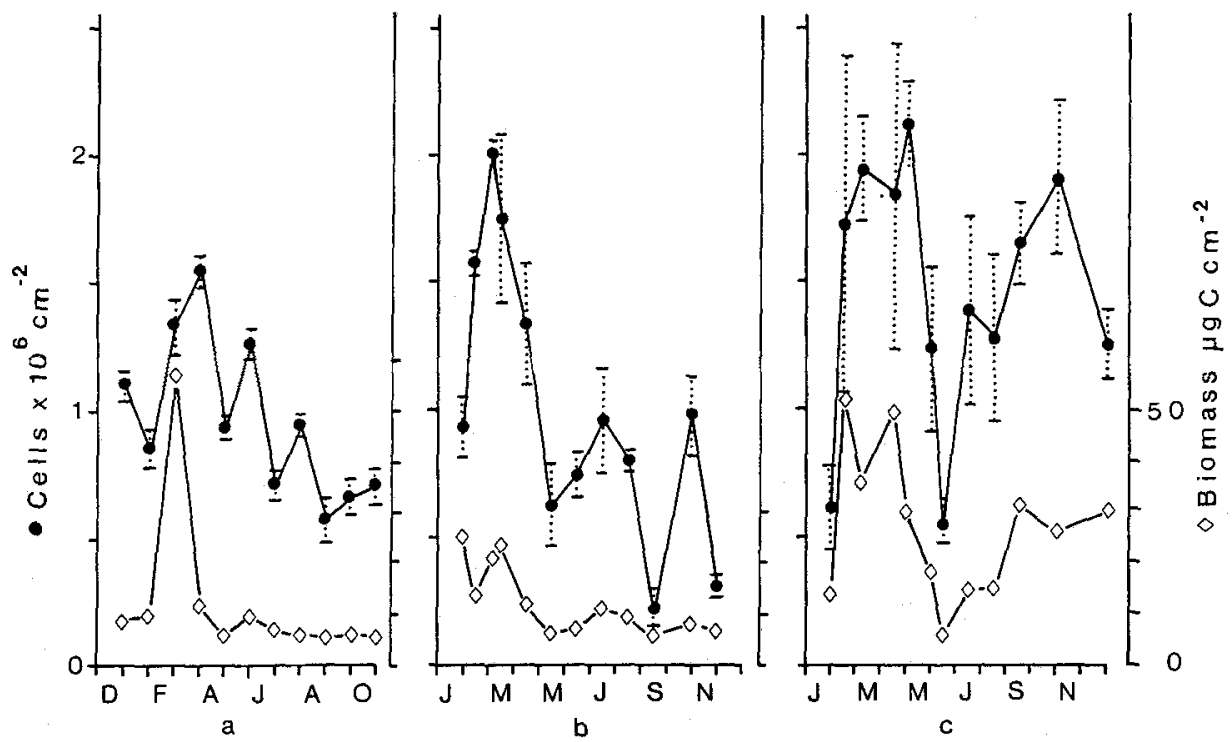

Fig. 3. Cell numbers of benthic diatoms (•), left scale, in the Arenicola-flat (a) (redrawn from Asmus, 1982), seagrass-bed (b) and Nereis-Corophium-belt (c) with standard deviation (dotted line) in the course of a year. The microphytobenthic biomass is indicated by $(0)$, right scale, redrawn from Asmus \& Asmus (1985)

(Table 1). Apart from this, the computer analysis confirmed the differentiation according to the macrobenthic assemblages for benthic diatoms also.

The diatoms were separated to a different degree into the three areas. A clear separation was found, especially in group 1 (Navicula sp. 2 to Podosira stelliger) (Table 1). The members of this group were mainly found in the Nereis-Corophium-belt, being less abundant in the seagrass-bed and only rarely found in the Arenicola-flat. Other distinct separations were found in the groups 6,13 and 14 (group 6: Actinocyclus octonarius Ehrenberg to Thalassiosira nordenskiöldii Cleve; group 13: Pleurosigma strigosum Wm. Smith to Navicula lyroides Hendey; group 14: Dimeregramma minor (Gregory) Ralfs and Navicula sp. 3). The members of these groups occurred more frequently in the Arenicola-flat than in the other two areas.

Other groups of species were more evenly distributed over the three areas, as for example group 3 (Nitzschia sp. 1 to Pleurosigma angulatum (Querkett) Wm. Smith) and group 8 (Rhaphoneis amphiceros (Ehr.) Ehrenberg to Nitzschia sp. 8).

Despite a partially incomplete separation, the assemblages identified coincided with the macrobenthic assemblages.

As, on the other hand, the results of the analysis can be influenced by inclusion or exclusion of species, runs were also done including or excluding dominant or rare species. These results are not given in detail here; but, in summary, they always revealed a separation of the Arenicola-flat from the other 2 areas. Under these conditions, records from the seagrass-bed and the Nereis-Corophium-belt were mixed to different degrees. 


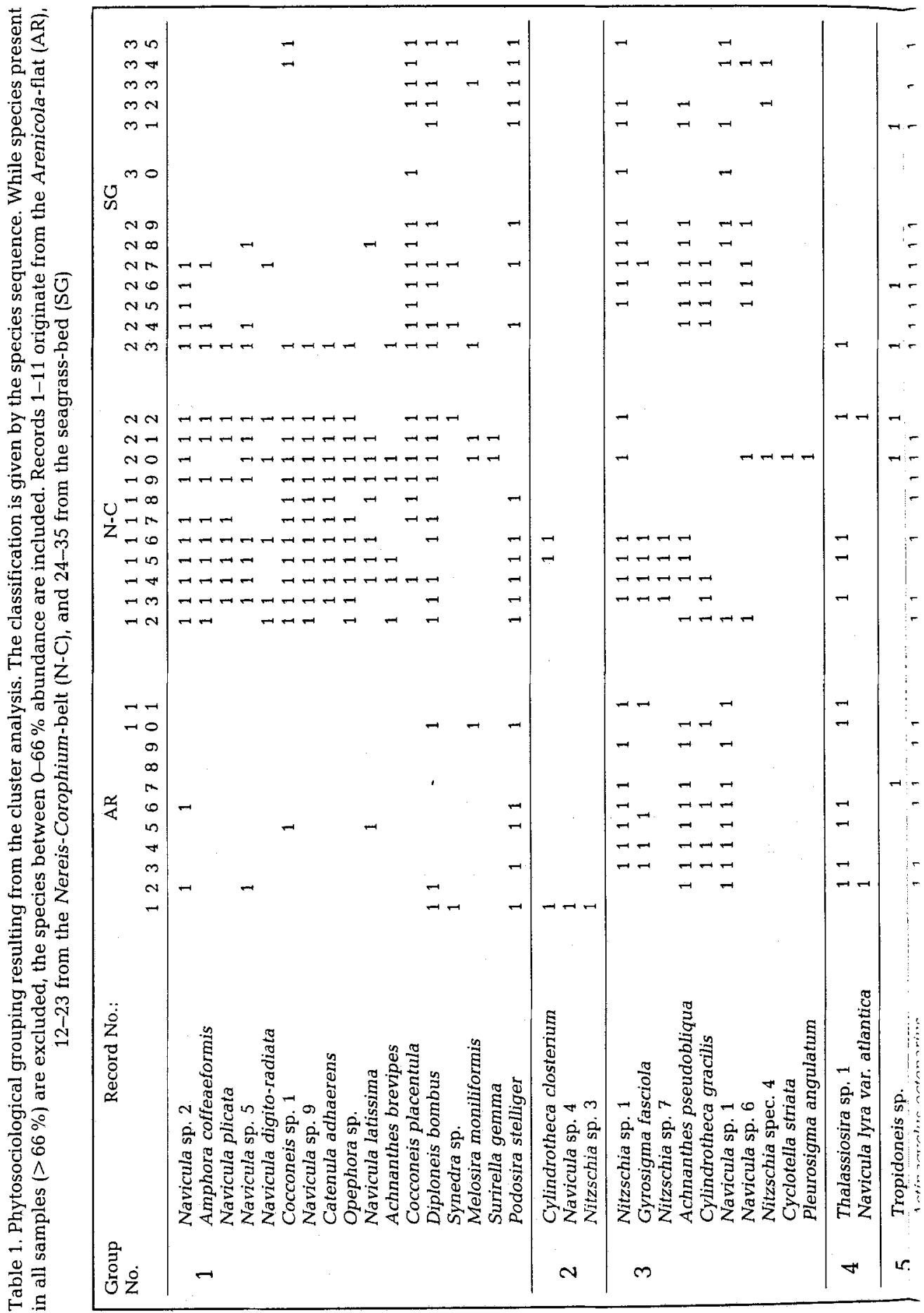




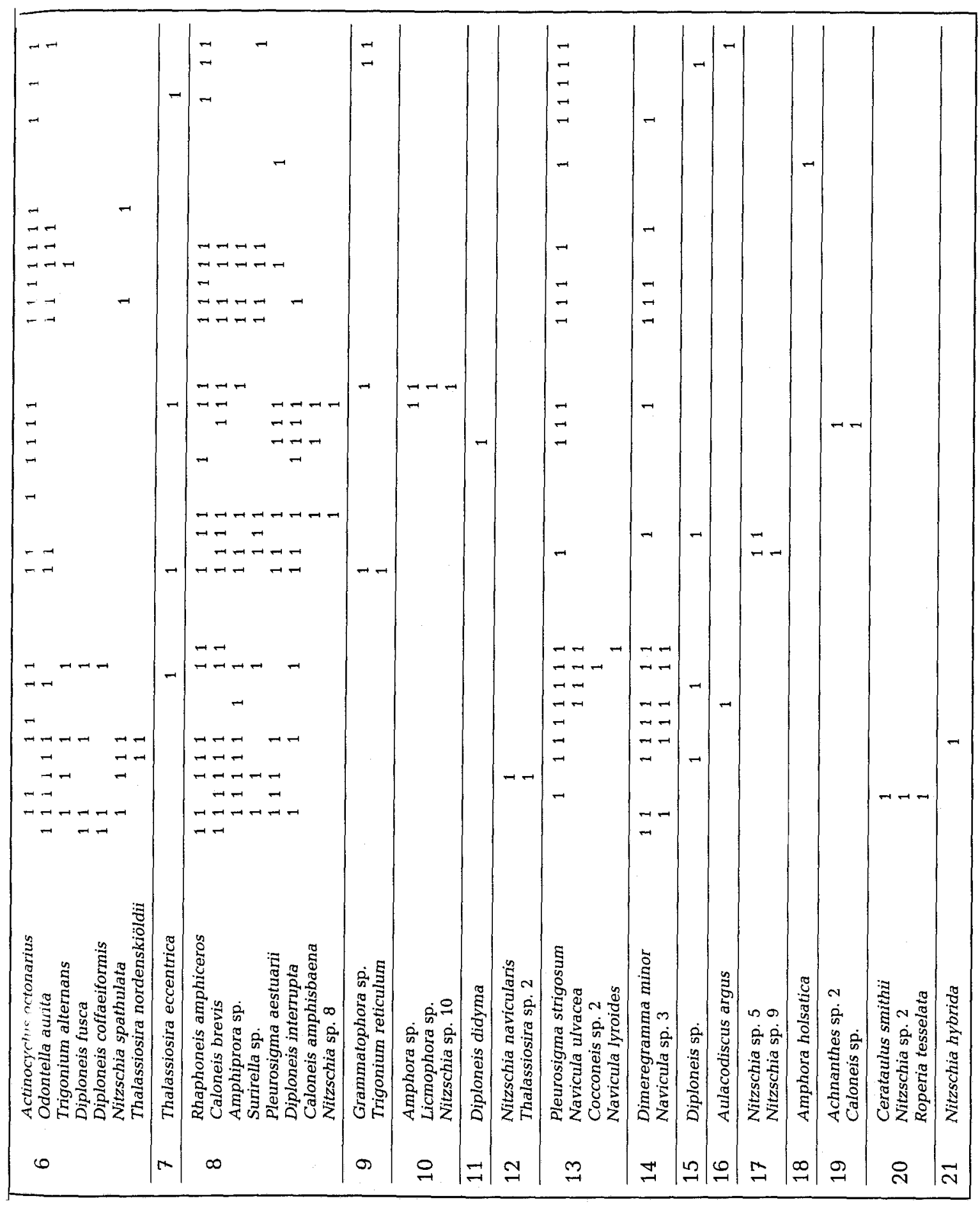


In all, there is a strong indication of a separation into different diatom assemblages on this sandy tidal flat from the high water line down into deeper water. The separation of the assemblage in the area of the deepest water (Arenicola-flat) from the higher assemblages was clearer than the separation between these two areas (seagrass-bed and Nereis-Corophium-belt). Here, the diatom assemblages showed a gradual transition.

\section{Seasonal distribution of microalgal species}

The picture of a clear "spring bloom" of microbenthic algae emerged from the seasonal cluster analysis. In all three areas, special groups of diatoms occurring mainly in spring were separated (Figs 4, 5,6) from those with a bimodal distribution, recurring in autumn, and those being present all year round. The rare species were assembled in group 1, respectively, in all 3 dendrograms.

The grouping was done for each sampling area on the basis of cell numbers as well as on microalgal biomass. The first and largest groups of rare species were very similar in both runs in all three areas (Table 2), e.g. in the group 1 of the Arenicola-flat 20 species were identical in the runs, on the basis of either abundance or biomass. The smaller groups differed in their composition. The dendrograms shown in Figures 4 to 6 are based on biomass values.

In the Arenicola-flat (Fig. 4), group 1 (rare species) was subdivided into different seasons or months; for instance, those species occurring in April were united in one small subgroup (Cocconeis sp. 1 to Gyrosigma sp.). Groups 2 and 3 consisted of more abundant species with a bimodal distribution (group 2: December till May, reappearing in September). Species of group 3 developed a larger biomass in autumn than in spring. The groups 4,5 and 6 were composed of important spring species. From group 7 and onwards, the species were present nearly all the year round. The groups 7 to 10 showed the highest biomass in February, but differed in their seasonal distribution. At a greater distance than

Table 2. Corresponding microalgal groups in the cluster analysis for the same area, calculated either on the basis of cell number or biomass

\begin{tabular}{|c|c|c|c|c|}
\hline \multirow{2}{*}{\multicolumn{5}{|c|}{ 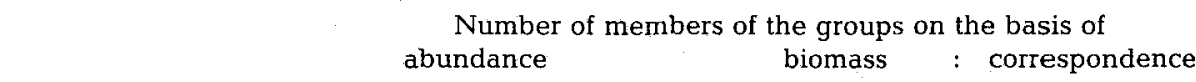 }} \\
\hline & & & & \\
\hline \multicolumn{5}{|c|}{ Arenicola-flat } \\
\hline group 1 & 21 & 21 & $:$ & 20 \\
\hline group 2 & 12 & 6 & $:$ & 6 \\
\hline group 9 & 2 & 2 & : & 2 \\
\hline \multicolumn{5}{|c|}{ seagrass-bed } \\
\hline group 1 & 20 . & 21 & : & 11 \\
\hline group 11 & 2 & 2 & $:$ & 2 \\
\hline \multicolumn{5}{|c|}{ Nereis-Corophium-belt } \\
\hline group 1 & 19 & 21 & $:$ & 15 \\
\hline group 2 & 20 & 21 & : & 14 \\
\hline group 3 & 7 & 5 & : & 3 \\
\hline group 7 & 3 & 4 & $:$ & 3 \\
\hline group 9 & 2 & 2 & : & 2 \\
\hline
\end{tabular}




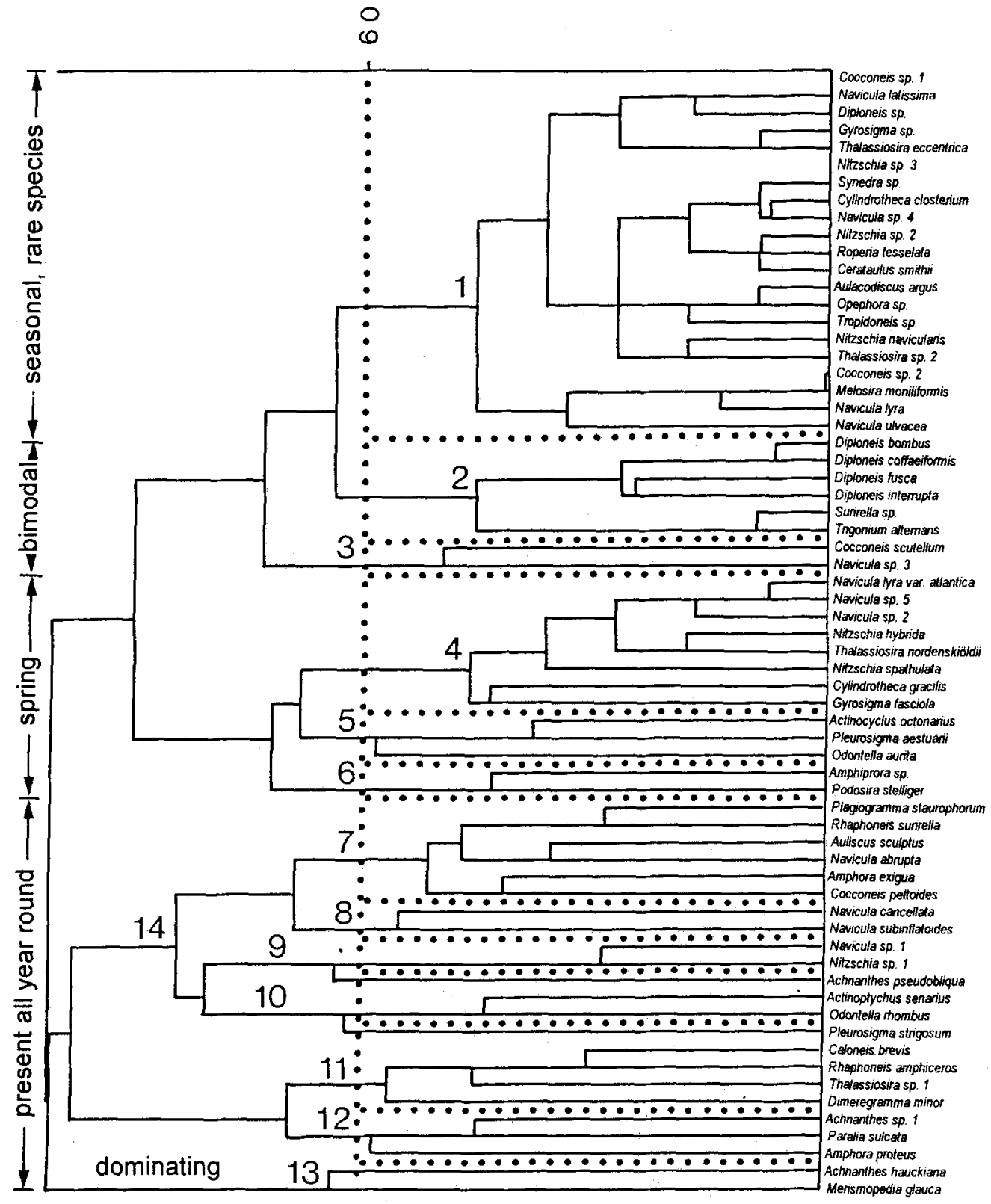

Fig. 4. Dendrogram of the cluster analysis of the microphytobenthic species assemblage in the Arenicola-flat on the basis of biomass $\left(\mu \mathrm{g} \mathrm{Cm}^{-2}\right)$. The distance of $60 \%$ has been chosen as limit for species groups. Dotted lines and numbers indicate different groups of species 
$60 \%$ (see Fig. 4), they were gathered into one group (indicated by 14). Group 11 was missing in summer (June, July, August). The members of group 12 were constantly present in low biomass values. Finally, Achnanthes hauckiana and Merismopedia glauca were connected (at a slightly greater distance than $60 \%$ ). These species are small but numerous, and thereby dominant throughout the year.

In the seagrass-bed (Fig. 5), group 1 was again subdivided into different months (June: Donkinia recta (Donkin) Grunow to Navicula latissima Gregory, August/September: Navicula lyra Ehrenberg to Melosira moniliformis (O. F. Müller) Agardh, and November to March: Eunotogramma sp. to Triceratium favus). Group 2 included the spring species. These species, Cylindrotheca gracilis (Brébisson) Grunow to Pleurosigma aestuarii (Brébisson) Wm. Smith, were more abundant than the members of group 1. Group 3 consisted of species with a bimodal distribution (spring and autumn), being low in biomass. The biomass in group 4 was higher in autumn than in spring. Some isolated species follow in the dendrogram. Group 5 was more abundant in spring than in autumn. The groups 6 to 16 were present nearly all the year round. Group 6 had mean biomass values and groups 7 and 8 were low in biomass. The species in groups 9 to 14 showed spring peaks and low values in summer. They were connected at a greater distance (16). Group 9 showed an autumnal increase. The epipelic species Pleurosigma strigosum Wm. Smith was abundant in summer. In September, Cocconeis scutellum Ehrenberg, the most important epiphyte of the seagrass in the study area, was simultaneously very numerous in the sediment. The predominant Achnanthes hauckiana stood nearly isolated in this seagrass-bed dendrogram. Merismopedia glauca was connected this time with the less abundant Amphora holsatica Hustedt which also had a maximum in June.

In the dendrogram of the Nereis-Corophium-belt (Fig. 6), group 2 included those species being present in spring. Only a small subgroup (Surirella gemma Ehrenb., Thalassiosira eccentrica Cleve and Dimeregremma minor (Gregory Ralfs) reappeared in autumn in low numbers, whereas all the other species were absent in autumn. In groups 3 to 6 there were species with a clear bimodal distribution. Most of these species developed a higher biomass in spring than in autumn. From group 7 and onwards, the species were present during all the year in different amounts and with peaks at different times. Group 7 included the small, numerous and biomass-dominating species Achnanthes hauckiana, Catenula adhaerens Mereschkowsky, Cocconeis sp. 1 and Amphora exigua Gregory. Group 8 comprised species with a little lower share in biomass. Groups 9 to 13 had a peak in common, either in spring (groups 9, 12,13) or in autumn (group 10). The last groups $(14,15)$ were present with low biomass values, showing peaks either in August (14) or in spring (15).

In the seasonal cluster analysis, the small, very abundant and biomass-dominating species were connected. The arrangement of the other species in the three areas differed considerably. Although many species occurred in all three areas, they were grouped together with different species in each area.

In all, the diatom assemblages in the upper and lower tidal flat areas differed. The assemblages were composed of mathematically separated groups, which did not show a clear co-occurrence of certain species, with the exception of the predominating, small species.

The microbenthic "spring bloom" was not only formed by those species united in the "spring-groups" (Figs 4 to 6). Also many species of the "bimodal" and "present all the 


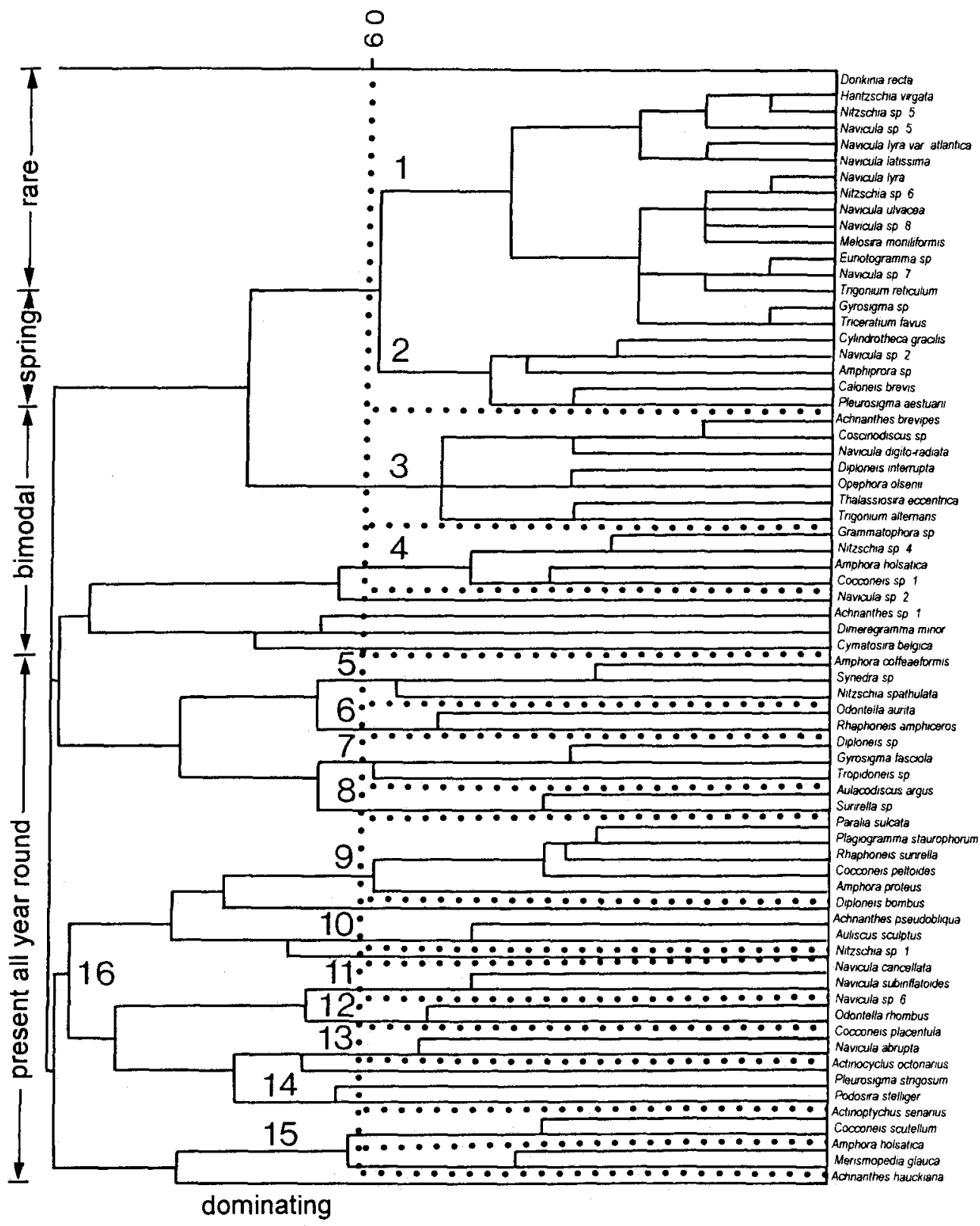

Fig. 5. Dendrogram of the cluster analysis of benthic microalgae in the seagrass-bed. Details according to Figure 4 


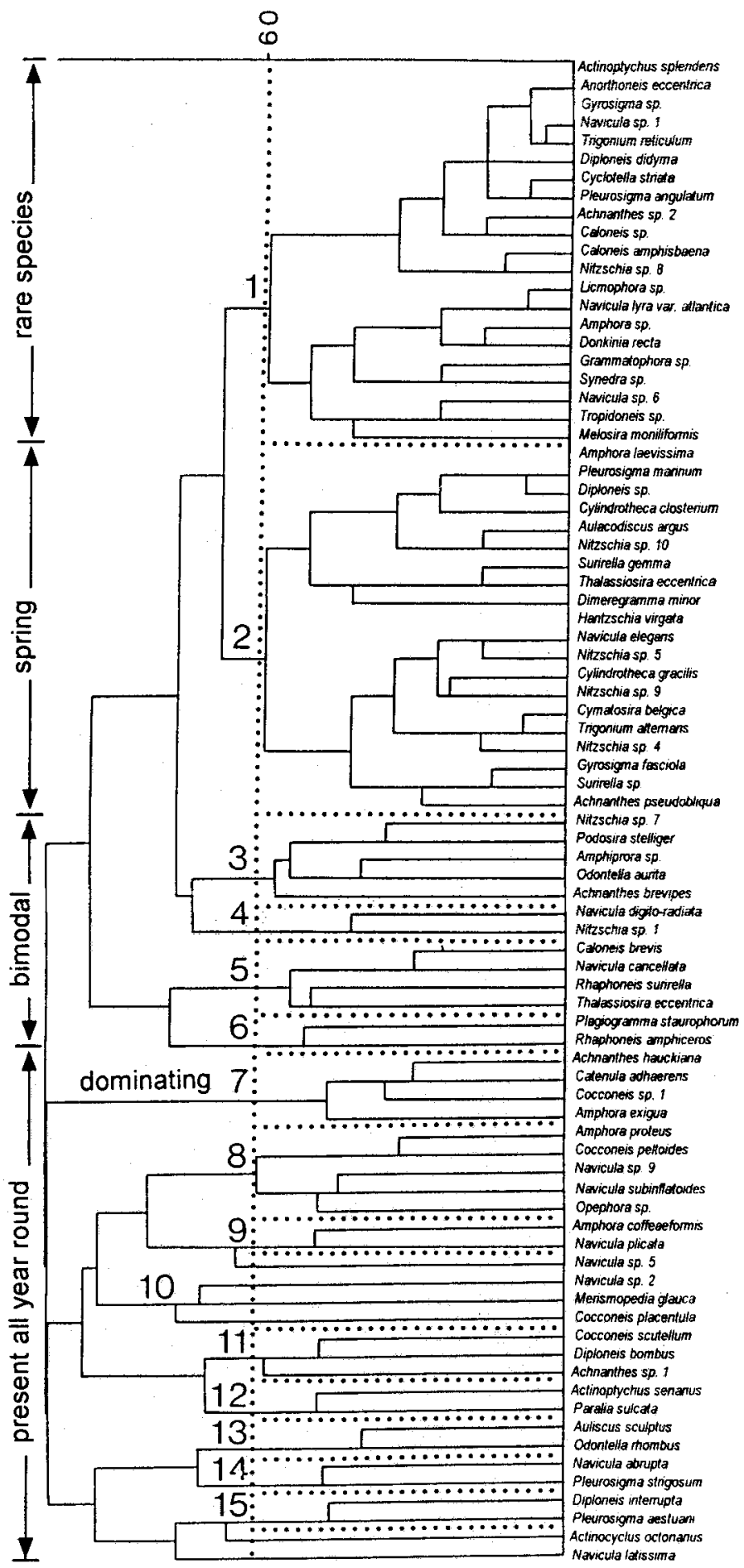

Fig. 6. Dendrogram of the cluster analysis of the microphytobenthos in the Nereis-Corophium-belt. For details, see legend of Figure 4 
year round"-groups showed maximal biomass values in spring. In total, the number of species showing a spring maximum was 24 in the Arenicola-flat, whereas 22 in the seagrass-bed and even 40 species had highest peaks in the Nereis-Corophium-belt in spring. (Rare species are excluded from this consideration.)

The species Cylindrotheca gracilis was present only in spring at all three sampling sites. From this it could be called a typical spring species in this area. C. gracilis was frequently accompanied by Gyrosigma fasciola (Ehrenb.) Griffith et Henfrey, Pleurosigma aestuarii, Odontella aurita and Amphiprora sp. at all three stations in spring.

Many species were missing in summer and returned in autumn. This trend was most pronounced in the Nereis-Corophium-belt, the only site with a strong autumnal microphytobenthic biomass increase. A few species evidenced a maximum in summer; one of these was Pleurosigma strigosum which could be called a typical summer species in the study area.

\section{DISCUSSION}

The species composition of diatoms of the sandy tidal flat of Königshafen is typical for sandy sediments moderately exposed to waves and currents. A dominance in numbers of epipsammic over epipelic diatoms is a constant pattern in environments of this kind (Round, 1965; Rao \& Lewin, 1976; Moss, 1977; Amspoker, 1977; Sundbäck, 1983; Whiting \& McIntire, 1985; Amspoker \& McIntire, 1986; Gätje, 1992). A high share of Achnanthes hauckiana in the diatom community was also found by Koppen \& Crow (1978), Colijn \& Dijkema (1981), Whiting \& McIntire (1985) and, to a lesser degree, by Amspoker \& McIntire (1978). A correspondingly high share of Achnanthes hauckiana in total cell number and cell volume (which in this study served as the basis for biomass calculation) was found by Sundbäck (1983). She named a study area in southern Sweden accordingly "Achnanthes hauckiana-association". The same could be done for the Arenicola-flat and the seagrass-bed in the Königshafen. Only in the Nereis-Corophiumbelt was the share of 3 other diatom species equal or even higher. Nevertheless, in Königshafen, there was a spatial and seasonal variation of diatoms without a clear indication of recurrent groups of diatoms. Little is known about the ecology of different diatom species and even less about interactions between species, although there are some successful studies (for review see Admiraal, 1984; Lüning \& Asmus, 1991). This area of research is open for further studies. Thus, the authors prefer to keep to the term "assemblage" instead of "association".

In this study on a sandy tidal flat, the small sized diatoms dominated. In a muddy area, Baillie (1987) found a bimodal size spectrum with abundant small, as well as large, diatom cells.

The whole species list shows a great similarity with those found by Colijn \& Koeman, (1975), Colijn \& Nienhuis (1978) and Colijn \& Dijkema (1981), all of whom worked further south in the Wadden Sea; therefore, this accordance could be expected. The species composition is also comparable to that of other estuaries in Europe and North America. Many benthic diatoms are widespread in temperate regions and some seem almost to have a cosmopolitan distribution (Kennett \& Hargraves, 1984).

Beside this agreement in the general characteristics of the diatom assemblages, it is difficult to compare, with data from literature, which species forms blooms under certain conditions. On the one hand, results on diatom abundance have been gained with 
different methods. The methods for sampling and processing of samples of benthic diatoms have not yet been standardized. On the other hand, long-term series of observations of benthic diatoms are scarce; very few authors have been able to study more than a 1 -year cycle (e.g. Sundbäck, 1983). Even this investigation in Königshafen includes results from a 1-year period only. However, the year-to-year variation might be great, as biomass and primary production measurements by Cadée (1980) revealed. The search for optimal methods for studying benthic diatoms qualitatively and quantitatively has not yet finished. At the moment, it is recommended that diatoms be separated from the sediment, either by the Ludox-method (de Jonge, 1979) or by ultra sonification (Colocoloff \& Colocoloff, 1973). Living diatoms can be distinguished from dead ones in a fluorescence microscope, and electron microscopy is necessary for the identification of many species. When this study was done, the above equipment was not readily available. Thus, epipelic diatoms were separated from epipsammic ones by shaking the samples, and cell counts could only be made in a light microscope without epifluorescence equipment. An electron microscope was used for better identification of species. Cluster analyses are very valuable tools for clarifying the structure of these multispecies diatom assemblages.

Despite methodological differences, some concurrent features can be found. A spring peak in microphytobenthic biomass was found by Taasen \& Høisæeter (1981) at a shallow station $(2 \mathrm{~m})$ in their study area (Lindasspollene, western Norway); the peak occurred in deeper water later in the year. In the northern Baltic, Snoeijs \& Kautsky (1989) also found a peak in early spring on rocky substrate. In the Elbe estuary, a spring bloom occurred in May (Gätje, 1992). In the Ems-Dollard estuary, the bloom started in March, reaching its maximum in May-June (Colijn \& Dijkema, 1981). Here, the abundance of benthic diatoms was minimal in summer, as was also found in a rocky area in Australia (Underwood, 1984).

In this study, the microphytobenthic biomass was highest on the uppermost part of the tidal flat. This is in accordance with findings, by Van der Werff (1960), Colijn \& Nienhuis (1978), Coles (1979), Metaxas \& Lewis (1992) and Gätje (1992). Contrary to these results, other authors found a higher abundance of benthic diatoms in deeper waters, as long as light was sufficient (Aleem, 1950; Round, 1971; Riznyk \& Phinney, 1972; Nicotri, 1977; Underwood, 1984). In these areas, the physiological stress for the diatoms was higher in the upper part of the shore, whereas in Königshafen, neither desiccation nor waves were so strong that diatoms were hampered in their growth in the upper part of the flat. Light was presumably saturating for short-term photosynthesis from the uppermost down to the Arenicola-flat (more than $200 \mu \mathrm{mol} \mathrm{m} \mathrm{m}^{-2} \mathrm{~s}^{-1}$, Asmus unpubl.).

An important point for coastal food webs is the timing of benthic diatom blooms. In the year of the investigation, the diatoms formed a high biomass beneath the ice as early as January/February before the benthic macrofauna became active. When the temperature rose in spring, a good basis for grazing benthic fauna was in stock. Grazing is an important factor in reducing diatom biomass (Coles, 1979; van den Hoek et al., 1979; Taasen \& Høisæter, 1981; McClatchie et al., 1982; Underwood, 1984; Asmus \& Asmus, 1985; Baillie, 1987; Kawamura \& Hirano, 1992). In Königshafen, the grazing pressure by Hydrobia ulvae was intense in the seagrass-bed; it was lower in the Arenicola-flat and lowest in the Nereis-Corophium-belt (Asmus \& Asmus, 1985). The primary production of 
benthic microalgae was highest in summer in Königshafen (Asmus \& Asmus, 1985). This does not necessarily result in a high biomass of benthic diatoms. Grazing and bioturbation are also highest in summer. In the Arenicola-flat, the stability of the sediment is lower than in the other two areas, due to heavy bioturbation by the lugworm. Bad weather with rain and storms, and the resulting physical disturbances of the sediment, may also reduce benthic diatom abundance (de Jonge, 1992).

In addition to the basic importance in ecosystem analysis, diatoms can be indicators of eutrophication and pollution. For freshwater, Lange-Bertalot $(1978 ; 1979)$ successfully developed a system for determining water quality on the basis of diatom species composition. Such a system is lacking for marine environments. Although many benthic diatoms seem to be capable of adapting to a comparatively wide regime of environmental factors, there are some studies showing the possible reactions of benthic diatoms to a deterioration of water quality. Snoeijs (1989) found that in winter the discharge of cooling water induced a bloom of benthic diatoms through rising water temperature. Although sediment porewater contains higher nutrient concentrations than the overflowing water, benthic diatoms are not generally nutrient saturated. Benthic diatoms were promoted by the addition of nutrients (Sundbäck \& Snoeijs, 1991). Thus, there are distinct reactions of benthic diatoms to eutrophication. Dense diatom mats were found in eutrophic areas, especially when grazing animals died off (Wilkinson et al., 1986). These diatoms and also macroalgae in polluted or eutrophic environments are at times composed of species often present in insignificant amounts and becoming dominant, almost to the exclusion of other species, under polluted conditions (Wilkinson et al., 1986). This also means that the food web of the affected area would be based on different kinds of cells and algae.

This investigation reveals that assemblages of benthic microalgae on a sandy tidal flat are separated into spatial and seasonal groups of mainly epipsammic species typical for sandy sediments. An intense spring bloom was observed. The interpretation of this succession remains quite speculative unless the ecology of benthic diatoms is elucidated by further investigations.

Acknowledgements. We appreciate the help of Gerhard Drebes in questions of diatom taxonomy, and the permission by Michael Meyer to use his computer programme for the cluster analysis. Gabriele Kredel greatly improved the English. Financial support was given by the FriedrichNaumann-Stiftung and by the Ministry for Research and Technology. This is publication no. 129 of the project "Ecosystem Research Wadden Sea".

\section{LITERATURE CITED}

Admiraal, W., 1984. The ecology of estuarine sediment-inhabiting diatoms. In: Progress in Phycological Research 3. Ed. by F. E. Round \& G. Chapman, Biopress, Bristol, 269-322.

Aleem, A. A., 1950. Distribution and ecology of British marine littoral diatoms. - Ecology 38, 75-106.

Amspoker, M. C., 1977. The distribution of intertidal epipsammic diatoms on Scripps Beach, La Jolla, California, USA. - Bot. Mar. 20, 227-232.

Amspoker, M. C. \& McIntire, C. D., 1978. Distribution of intertidal diatoms associated with sediments in Yaquina estuary, Oregon. - J. Phycol. 14, 387-395.

Amspoker, M. C. \& McIntire, C. D., 1986. Effects of sedimentary processes and salinity on the diatom flora of the Columbia River Estuary. - Bot. Mar. 29, 391-399.

Asmus, R., 1982. Field measurements on seasonal variation of the activity of primary producers on a sandy tidal flat in the northern Wadden Sea. - Neth. J. Sea Res, 16, 389-402. 
Asmus, R., 1984. Benthische und pelagische Primärproduktion und Nährsalzbilanz. - Ber. Inst. Meereskunde, Univ. Kiel, 131, 148 pp.

Asmus, H. \& Asmus, R., 1985. The importance of grazing food chain for energy flow and production in three intertidal sand bottom communities of the northern Wadden Sea. - Helgoländer Meeresunters. 39, 273-301.

Austen, I., 1990. Geologisch-sedimentologische Kartierung des Könighafens (List auf Sylt) und Untersuchung seiner Sedimente. Diplomthesis, Univ. Kiel, 99 pp.

Baillie, P. W., 1987. Diatom size distribution and community stratification in estuarine intertidal sediments. - Estuar., Coast. and Shelf Sci. 25, 193-209.

Bock, H. H., 1974. Automatische Klassifikation. Vandenhoek and Ruprecht, Göttingen, $480 \mathrm{pp}$.

Bölter, M. \& Meyer, M., 1986. Structuring of ecological data sets by methods of correlation and cluster analysis. - Ecological modelling 32, 1-13.

Bölter, M., Meyer, M. \& Probst, B., 1980. A statistical scheme for structural analysis in marine ecosystems. - Ecological Modelling 9, 143-151.

Brockmann, C., 1935. Diatomeen und Schlick im Jade-Gebiet. Abh. Senckenberg. Naturf. Ges. 430, $1-64$.

Brockmann, C., 1950. Die Watt-Diatomeen der schleswig-holsteinischen Westküste. - Abh. Senckenberg. Naturf. Ges. 478, 5-26.

Cadée, G. C., 1980. Reappraisal of the production and import of organic carbon in the Western Wadden Sea. - Neth. J. Sea Res. 14 (3/4), 305-322.

Cleve-Euler, A., 1951-55. Die Diatomeen von Schweden und Finnland.- Kongl. Svenska Vetenskapsakademies Handlingar, Stockholm. Teil I-V.

Coles, S. M., 1979. Benthic microalgal populations on intertidal sediments and their role as precursors to salt marsh development. In: Ecological processes in coastal environments. Ed. by R. L. Jefferies \& A. J. Davy, Bradwell, Oxford, 25-42.

Colijn, F. \& Dijkema, K. S., 1981. Species composition of benthic diatoms and distribution of chlorophyll a on an intertidal flat in the Dutch Wadden Sea. - Mar. Ecol. Prog. Ser. 4, 9-21.

Colijn, F. \& Koeman, R., 1975. Das Mikrophytobenthos der Watten, Strände und Riffe um den hohen Knechtsand in der Wesermündung. - Jahresber. d. Forschungsstelle Küste, Norderney, 53-83.

Colijn, F. \& Nienhuis, H., 1978. The intertidal microphytobenthos of the "Hohe Weg" shallows in the german Wadden Sea. - Jahresber. d. Forschungsstelle Küste, Norderney, 149-174.

Colocoloff, M. \& Colocoloff, C., 1973. Mise en évidence par l'emploi des ultra-sons de la densité élevée des diatomées des fonds sableux. - Rapp. Comm. int. Mer Médit. 21(9), 669-672.

Edler, L., 1979. Recommendations on methods for marine biological studies in the Baltic Seaphytoplankton and chlorophyll. - Baltic mar. Biol. Publ. 5, 1-38.

Gätje, C., 1992. Artenzusammensetzung, Biomasse und Primärproduktion des Mikrophytobenthos des Elbe-Ästuars. Thesis, Univ. Hamburg, 211 pp.

Hendey, N. I., 1964. An introductory account of the smaller algae of British coastal waters, part V: Bacillariophyceae. Ministry of Agriculture, Fisheries and Food, Her Majesty's Stationary Office, London, $317 \mathrm{pp}$.

Huang, R. \& Boney, A. D., 1984. Growth interactions between littoral diatoms and juvenile marine algae. - J. exp. mar. Biol. Ecol. 81, 21-45.

Hustedt, F., 1927-30, 1931-59, 1961-66. Die Kieselalgen Deutschlands, Österreichs und der Schweiz unter Berücksichtigung der übrigen Länder Europas sowie der angrenzenden Meeresgebiete. Teil 1-3. - L. Rabenhorsts Kryptogamen-Flora von Deutschland, Österreich und der Schweiz, Bd. 7, Leipzig, Teil 1: 1-920, Teil 2: 1-845, Teil 3: 1-816.

Hustedt, F., 1939. Die Diatomeenflora des Küstengebietes der Nordsee vom Dollart bis zur Elbmündung. - Abh. Naturwiss. Ver. Bremen 31, 572-677.

Hustedt, F., 1959. Die Diatomeenflora der Unterweser von der Lesummündung bis Bremerhaven mit Berücksichtigung des Unterlaufs der Hunte und Geste. - Veröff. Inst. Meereforsch. Bremerh. 6, 13-176.

Jonge, de V. N., 1979. Quantitative separation of benthic diatoms from sediments using density centrifugation in the colloidal silica Ludox-TM.- Mar. Biol. 51, 267-278.

Jonge, de V. N., 1992. Physical processes and dynamics of microphytobenthos in the Ems Estuary (The Netherlands). Thesis, University of Groningen, $176 \mathrm{pp}$. 
Kawamura, T. \& Hirano, R., 1992. Seasonal changes in benthic diatom communities colonizing glass slides in Aburatsubo Bay, Japan. - Diatom Research 7(2), 227-239.

Kennett, D. M. \& Hargraves, P. E., 1984. Subtidal benthic diatoms from a stratified estuarine basin. Bot. Mar. 27, 169-183.

Koppen, J. D. \& Crow, J. H., 1978. Some midsummer diatom assemblages along the saline gradient of a small coastal stream in Kachemak Bay, Alaska. - Bot. Mar. 21, 199-206.

Korte, V. L. \& Blinn, D. W., 1983. Diatom colonization on artificial substrata in pool and riffle zones studied by light and scanning electron microscopy. - J. Phycol. 19, 332-341.

Lange-Bertalot, H., 1978. Diatomeen-Differentialarten anstelle von Leitformen: ein geeignetes Kriterium der Gewässerbelastung.- Arch. Hydrobiol., Suppl. 51, 393-427.

Lange-Bertalot, H., 1979. Pollution tolerance of diatoms as a criterion for water quality estimation. Nova Hedwigia Beih. 64, 285-304.

Lüning, K. \& Asmus, R., 1991. - Physical characteristics of littoral ecosystems, with special reference to marine plants. In: Ecosystems of the world, 24. Intertidal and littoral ecosystems. Ed. by A. C. Mathieson \& P. H. Nienhuis, Elsevier, Amsterdam, 7-26.

McClatchie, S., Juniper, S. K. \& Knox, G. A., 1982. Structure of a mudflat diatom community in the Avon-Heathcote Estuary, New Zealand. - New Zealand J. Mar. Freshw. Res. 16, 299-309.

McIntire, C. D. \& Overton, W. S., 1971. Distributional patterns in assemblages of attached diatoms from Yaquina Estuary, Oregon. - Ecology, 52, 758-777.

Metaxas, A. \& Lewis, A. G., 1992. Diatom communities of tidepools: The effect of intertidal height. Bot. Mar. 35, 1-10.

Meyer, M., 1983. Strukturanalytische Untersuchungen am Phytobenthos der Kieler Bucht mittels mathematischer Methoden (zum Problem der Anwendung klassischer und moderner Konzepte in der marinen Vegetationskunde). - Thesis, Univ. Kiel, 215 pp.

Meyer, M. \& Bölter, M., 1981. Programmblock zur Strukturanalyse von Ökosystemen. Reports Sonderforschungsbereich (SFB) 95, University of Kiel, No. 58, 47 pp.

Moss, B., 1977. Adaptations of epipelic and epipsammic freshwater algae. - Oecologia 28, $103-108$.

Nicotri, M. E. 1977. Grazing effects of four marine intertidal herbivores on the microflora. - Ecology, $58,1020-1032$.

Rao, V. N. R. \& Lewin, J., 1976. Benthic marine diatom flora of False Bay, San Juan Island, Washington. - Syesis 9,173-213.

Riznyk, R. Z. \& Phinney, H. K., 1972. The distribution of intertidal phytopsammon in an Oregon estuary. - Mar. Biol. 13, 318-324.

Round, F. E., 1965. The epipsammon; a relatively unknown freshwater algal association. - Br. phycol. Bull. 2, 456-462.

Round, F. E., 1971. Benthic marine diatoms. In: Oceanogr. Mar. Biol. Ann. Rev. 9. Ed. by H. Barnes, G. Allen \& Unwin Ltd., London, 83-139.

Snoeijs, P. J., 1989. Ecological effects of cooling water discharge on hydrolittoral epilithic diatom communities in the northern Baltic Sea. - Diat. Res. 4(2), 373-398.

Snoeijs, P. J. M. \& Kautsky, U., 1989. Effects of ice-break on the structure and dynamics of a benthic diatom community in the northern Baltic Sea. - Bot. Mar. 32, 547-562.

Steinhausen, D. \& Langer, K., 1977. Einführung in Methoden und Verfahren der automatischen Klassifikation. De Gruyter, Berlin, New York, 207 pp.

Sundbäck, K., 1983. Microphytobenthos on sand in shallow brackish water, Öresund, Sweden. Thesis, Univ. Lund, $209 \mathrm{pp}$.

Sundbäck, K., 1987. The epipsammic marine diatom Opephora olsenii Möller. - Diatom Res. 2(2), 241-249.

Sundbäck, K. \& Medlin, L. K., 1986. A light and electron microscopic study of the epipsammic diatom Catenula adhaerens Mereschkowsky. - Diatom Res. 1(2), 283-290.

Sundbäck, K. \& Snoeijs, P., 1991. Effects of nutrient enrichment on microalgal community composition in a coastal shallow-water sediment system: An experimental study. - Bot. Mar. 34, 341-358.

Taasen, J. P. \& Høisæter, T., 1981. The shallow-water soft-bottom benthos in Lindåspollene, western Norway. 4. Benthic marine diatoms, seasonal density fluctuations. - Sarsia 66, 293-316.

Underwood, A. J., 1984. The vertical distribution and seasonal abundance of intertidal microalgae on a rocky shore in New South Wales. - J. exp. mar. Biol. Ecol. 78, 199-220.

Van den Hoek, C., Admiraal, W., Colijn, F. \& de Jonge, V. N., 1979. The role of algae in the 
ecosystem of the Wadden Sea: a review. - Flora and vegetation of the Wadden Sea. Ed. by W. J. Wolff, Leiden, 9-118.

Van der Werff, A., 1960. Die Diatomeen des Dollart-Emsgebietes. - Verh. Kon. Ned. Geol. Mijnb.k. Gen., Geol. Ser, Dl XIX, Symposium Ems-Estuarium (Nordsee), 153-201.

Van der Werff, A. \& Huls, H., 1957-1974. Diatomeeenflora van Nederland. Koeltz, Koenigstein.

Whiting, M. C. \& McIntire, C. D., 1985. An investigation of distributional patterns in the diatom flora of Netarts Bay, Oregon, by corresponding analysis. - J. Phycol. 21, 655-661.

Wilkinson, M., Fuller, I. \& Rendall, D., 1986. The attached algae of the Clyde and Garnock Estuaries.- Proc. Royal Soc. Edinburgh, 90B, 143-150. 